\title{
1. What is biopolitics?
}

Steven A. Peterson and Albert Somit

\section{INTRODUCTION}

This volume explores the many dimensions of biopolitics, or, as some prefer, biology and politics or some other designation (Liesen and Walsh, 2012). The focus of this field within political science is the multiple ways by which politics and the life sciences are interlinked. One approach might feature policy implications from the life sciences (a whole section in this volume explores "biopolicy"). Another approach would be the use of biological theory and principles and findings to explain political behavior and institutions (several chapters in the book examine this linkage). Biopolitics provides insights into many of the fields of political science, as the reader will see in later chapters.

This chapter, though, steps back and speaks of the field of biopolitics as a whole. First issue: how has this field developed? A history is offered by Robert Hunt Sprinkle in a subsequent chapter in this work (see also Hines, 1982; Johnson, 2011; Founder's Forum, 2011, a special issue of Politics and the Life Sciences, publishes essays about and by some of the "Founders" of biology and politics and also illuminates the field's history). What is the promise of biology and politics? What contributions have been made? This chapter is designed to place the remainder of the Handbook of Biology and Politics in a larger context.

As will be noted throughout this work, biological factors have become increasingly recognized within the discipline of political science. One index of this can be assessed using two successive versions of a handbook of political science. In A New Handbook of Political Science, published in 1996, there is no reference to biology as a relevant field for political science (Goodin and Klingemann, 1996). In the next version, The Oxford Handbook of Political Science, published in 2009, the lead essay speaks of one possible candidate for "the next big thing" in the study of political science as the use of evolutionary models (Goodin, 2009a: 25-7). And the index to this massive volume contains a number of references to evolutionary theory's relevance in several other chapters. Relevant, too, is the reality that citations of the Alford et al. (2005) article on genetic influences on political behavior make it one of the most downloaded articles from the American Political Science Review.

\section{AN INFORMAL (AND BRIEF) HISTORY OF BIOPOLITICS}

Allusions to biological influences on human politics are as old as the Greek philosophers (for more detail, see Peterson, 1976). Plato's metaphor of bronze, silver, and gold, developed in The Republic, is an early analogue to later suggestive work on the genetic bases of human behavior. Here, Plato argued that certain people were born with the capacity to rule; most, however, were born with the more limited capacity to be "producers." Aristotle 
referred to inherent qualities of humans as shaping their behavior. In his Politics, he noted "that some should rule, and others be ruled is a thing not only necessary but expedient; from the hour of their birth, some are marked out for subjection, others for rule." And, of course, he referred to humans as political animals, although we cannot really ascribe contemporary biological underpinnings to that statement.

Metaphor was one manner in which biological explanations were applied to politics. Marsiglio of Padua (1956) developed one such metaphorical argument. The state was like an animal, composed of interdependent parts. When the state's parts worked smoothly, there was tranquility. The "parts" included agriculture, artisans, the military, financial interests, the priestly class, and judicial representatives. Jean-Jacques Rousseau used biological metaphor in The Social Contract. There, he likened the force and will required to move the body to the legislative and executive power of the state. Later, he noted that the "government is on a small scale what the body politic which includes it is on a large scale. It is a moral person endowed with certain faculties."

Herbert Spencer (1969) later on used a clearly organismic analogy, as did early key figures in the development of American political science - such as Woodrow Wilson. In his Constitutional Government, for instance, Wilson noted that "government is not a machine but a living thing. It falls, not under the theory of the universe, but under the theory of organic life." Significantly, he goes on to state that: "It is accountable to Darwin, not to Newton" (Wilson, 1908: 56). Raymond Gettell stressed the similarity of political evolution to biological evolution. He observed that political society evolved from the simple to the complex (from tribe to nation to state) "as in the evolution of all organisms" (1933: 111).

In the 1800s and early 1900s, biological explanations of politics based on racial analysis began to become more common. Sir Francis Galton, cousin of Charles Darwin, attempted empirical analysis of racial differences (Galton, 1892). One approach was to determine the number of famous people or great men within a variety of different cultures; the greater the proportion of great men in a population, he contended, the more superior that culture. He concluded that the English "race" was among the most superior of his time. However, he also concluded that the ancient Athenians were as superior over the contemporary English as the English were over Africans. Jean Bodin (1962) used racial analysis to explain distinctions across different types of people. He suggested that different human groupings had different humors and that governments would thus vary across nations as a result of the disparate natures of the peoples.

J.K. Bluntschli referred to the mental inequality across four races (red, yellow, black, and white) and the resulting unequal capacity for the development of nations. He wrote (1895: 19): "In every encounter with white races or men, [the black] has at once given in to them ... Childish by nature, it is meant to be educated and ruled by higher nations." The red race was deemed incapable of political action and Bluntschli hypothesized that the Inca Empire was actually developed by Aryans. It goes without saying that he felt that the white race was the most fit to rule.

Finally, some analysts determined that there were public policy implications from racial or evolutionary analyses. John W. Burgess, another key figure in the evolution of American political science, argued that the Teutonic peoples were uniquely qualified to produce political societies of eminence. One deduction from this for Burgess was that the Teutonic societies would have to carry their genius to other parts of the world where 
peoples were incapable of creating advanced civilization (Burgess, 1890). Thus, racial analysis led to the argument for colonial expansionism. Madison Grant perhaps took this perspective to its starkest conclusion. In the introduction to the fourth edition of his work, The Passing of the Great Race, Grant argued for "the decision of Congress of the United States to adopt discriminatory and restrictive measures against the immigration of undesirable races and peoples" (Grant, 1923: xxviii). In short, his sense that there was differentiation by race in the quality of people led him to argue for official discrimination against the "lower" sort.

James Dealey used eugenics as an intellectual basis for public policy proposals. He asserted that the study of eugenics could provide a sound basis for legislation. He said that legislators (1921: 263) "should study the principles of horticulture and stirpiculture as worked out in genetics and make applications of these to the development of racial stock."

In the twentieth century, we see some early interest in a more substantive tie between biology and politics. Graham Wallas' book, Human Nature in Politics (1908), was influenced by Darwin and contended, in part, that non-rational elements affected political behavior. In the December, 1956 issue of the American Political Science Review, Harold Lasswell spoke of political science as a discipline and profession "in relation to the impact of the physical and biological sciences ... upon the life of man" (Lasswell, 1956: 961). He notes some implications of evolution, genes, and brain science for humans. In a later essay (Lasswell, 1968), he notes that comparative politics can be enriched by comparisons among humans, monkeys, and apes. W.J.M. Mackenzie (1967) observed that political scientists ought to regard their discipline as a part of biological politics. A much more recent essay also lays out linkages between biology and politics via an "emerging science of human nature" (Fowler and Schreiber, 2008).

One factor playing a role in the current development of a biological approach to the study of politics was a growing discontent with the "state of the discipline" in the 1960s and 1970s. That discontent was reflected in an extraordinarily nasty, no-holds-barred dispute between advocates and opponents of behavioralism and a resulting sense among many members of the profession of "a plague on both your houses"; a discontent which contributed to the creation and brief popularity of the New Caucus For Political Science; a discontent which would be voiced, to mention only two of the critics, by Glendon Schubert (1976) and John Wahlke (1976), and which eventually became the central theme of Wahlke's American Political Science Association (APSA) presidential address (1979).

As Wahlke saw it, behavioralism, which had essentially dominated the discipline since the early 1950s, had failed to make appreciable progress towards its professed goal: a scientific political science. In fact, he argued, given its assumptions about behavior and its research methodology, behavioralism was incapable of achieving that objective. It was time to try a radically different approach by turning to a discipline that had recently achieved such impressive advances: biology, in general, and ethology and evolutionary theory in particular.

The contemporary interest in biopolitics can be traced most directly to the $1960 \mathrm{~s}$ (although note Mackenzie, 1977, on the use of the term "biopolitics" by Morley Roberts many years earlier). Several different events/publications during this decade serve as the baseline for subsequent developments. In 1964, Lynton Caldwell published a piece in the Yale Review on environmental policy (Caldwell, 1964). In 1963, James C. Davies published his book, Human Nature in Politics, which suggested biological components to 
human political behavior. Finally, in 1967, at a meeting of the Southern Political Science Association in New Orleans, Albert Somit (1968) and Robert Pranger (1967) presented papers on biological bases of political behavior. Which of these starting points one might embrace is quite beside the point. It is clear that the 1960s marked the beginning of an interest in the linkage between biology and politics.

The institutionalization of biology and politics began in the 1970s. The International Political Science Association formally recognized biology and politics as an area when it approved its status as a research committee in 1972 - one of the earliest organizations so designated (Research Committee \# 1 was approved in 1970) (Somit and Peterson, 2013). In 1980, the Association for Politics and the Life Sciences (APLS) was launched at a meeting of the American Political Science Association. In 1982, the first issue of the Association's journal, Politics and the Life Sciences, was published (see Goetze, 2013).

\section{THE INTELLECTUAL CORE OF BIOLOGY AND POLITICS: EVOLUTIONARY THEORY}

The intellectual core of biopolitics is evolutionary theory (for example, see Darwin, 1859; Hamilton, 1964; Mayr, 1963). Scholars in this field begin with the assumption that human political behavior is a product of the evolutionary process. Therefore, to make sense of human politics, we need to understand evolution. Currently, the reigning paradigm is "neo-Darwinian theory." This combines Darwin's insights into natural selection with the knowledge from genetics.

The two work together to provide a powerful paradigm for explaining evolutionary change. The basic components of Darwin's theory are deceivingly simple (Somit and Peterson, 2011, p. 5):

First, more offspring are born than can survive, creating a struggle for existence, given the limitations on population that any environment can support.

Second, there is variation among organisms. Some of this variation increases odds of survival and subsequent reproductive success, whereas others may be more likely to lead to death and reduce the chances for reproductive success.

Third, the variations leading to increased chances of survival and reproductive success are transmitted from parent to offspring.

Natural selection is the process by which some individuals survive and reproduce and pass on their characteristics to the next generation. Some are "selected" for reproductive success, whereas others are not. Those characteristics leading to reproductive success are passed down through generations.

Darwin himself could not account for the process by which variations that were selected for passed from one generation to the next. Genetics provides the answer to that. Genes are the messengers between generations. An organism's structure and functioning is the result of the genetic structure in interaction with the larger environment. Natural selection selects for certain genes, as these genetic ensembles increase the odds of later reproductive success of the organism. The publication of Edward O. Wilson's Sociobiology (1975) explicitly applied neo-Darwinian theory to social behavior. While this had been discussed before, Wilson's application to human social behavior stirred controversy. Part of his argument 
was this: recall that an individual should behave in such a way as to increase the number of his or her genes in the next generation. There are two avenues toward this. First, by passing along one's genes directly, usually referred to as "individual reproductive success." Second, one can behave in such a manner as to increase the reproductive success of one's relatives, with whom one shares genes (Barash, 1982). The combination of individual reproductive success and that of relatives is termed "inclusive fitness," a key concept in sociobiology.

In any species, accordingly, the individual should behave in such a way as to maximize the number of his/her genes appearing in the next generation. This includes social behavior - and human political behavior is one specific element in social behavior. Applying Darwinian theory through the specific theoretical perspective of sociobiology, many in biopolitics have explored the impact of inclusive fitness on human political behavior (for example, see Somit and Peterson, 1997).

One of the central issues that distinguishes those in biopolitics from mainstream political science is the emphasis on the need to understand the evolutionary origins of the behavioral predispositions which Homo sapiens shares with all the other social primates and which significantly affect our political life. Profoundly influenced by ethology and contemporary evolutionary theory, those working in this area insist that we should give proper weight to the role played by nature as well as by nurture in shaping our social and political behavior. That insistence runs directly counter, of course, to the long-accepted disciplinary paradigm, which holds that human political behavior is learned and that possible genetically transmitted proclivities can and should be ignored.

\section{CONTRIBUTIONS TO THE MAINSTREAM}

Evolutionary theory, then, is at the heart of the study of biology and politics. However, other areas within the biological realm have been explored as sources for explaining a variety of aspects of the political. We illustrate with a brief literature review.

\section{Genetics}

Genetics has become one of the foci of the biopolitics of political behavior. One aspect of this is the use of twin studies. By comparing identical twins with fraternal twins, one can - according to the standard methodology - tease out the genetic impact on attitudes and behavior (for example, on methods, see Alford et al., 2005; Smith and Hatemi, 2013), although there are criticisms of this method (for example, Charney, 2011).

One study explores the genetic correlates of political attitudes (including ideology), using monozygotic versus dizygotic twins (identical versus fraternal) (Alford et al., 2005). Another examines the linkage of genes (assessed through a sample of twins in Denmark and the United States) on political trust, political efficacy, and political participation. Results suggest a similar level of heritability across cultures (Klemmensen et al., 2012).

\section{Brain Science}

An understanding of the structure and function of the human brain is also an important issue for students of biology and politics to be aware of. Robert Blank, in a subsequent 
chapter, discusses this in considerable detail; we will not consider this matter in any depth here.

However, we would like to briefly note some of the studies that try to link the brain with political thinking, behavior, orientations, and attitudes. One study used structural MRI and determined that political orientations are associated with brain structure in young adults. For instance, liberalism was associated with increased gray matter in the cingulate gyrus; greater conservatism was linked with increased volume of the right amygdala (Kanai et al., 2011). A study using EEG technology finds that subjects process information differently by trustworthiness of the source of the information. The authors conclude that (Boudreau et al., 2008) recording EEGs can add additional understanding of people's decisions to trust sources of information. Still another study used EventRelated Potential technology to study differences between liberals and conservatives. They found that liberalism was associated with anterior cingulate activity (Amodio et al., 2007).

\section{Subfields within Political Science - and Biological Analyses in Each}

To put a survey of biopolitical works in a somewhat different framework, we now note contributions to several of the mainstream areas within the discipline of political science. Many of these were published or presented many years ago. But part of our goal in this chapter is to show that there has been an abiding interest in the linkage between biology and politics for many decades. Hence, an historical perspective, with some emphasis on older works, places current research into a broader context.

\section{Political Behavior}

Above, several examples were cited to suggest that biomedical factors might influence the manifestation of people's political orientations, attitudes, and behavior. In this section, we consider how such variables might affect: (1) political participation, both conventional (voting in elections, working for candidates, contributing money to candidates or political causes) and unconventional (taking part in demonstrations and protests); (2) elite political behavior.

\section{Political orientations}

Health status can influence our political orientations. According to Schwartz (1976; Schwartz et al., 1975), poor health is associated with less positive views of the political world and a more passive, fatalistic attitude toward politics. In two samples of rural elderly, poor health correlated with lower levels of political efficacy and interest (Peterson, 1987, 1989). National Opinion Research Center data (from the General Social Survey) suggest that, at least in 1982 and 1984, healthier people are less apt to be politically alienated and more likely to be conservative (Peterson, 1988). In a study of rural older Americans, Peterson (1987) concluded that poor nutrition is associated with lower political efficacy.

\section{Political participation and behavior}

The most common type of political behavior is simply voting. Some studies have explored the effect of non-verbal communication on electoral preferences. Masters et al. (1986) 
presented televised images (with and without accompanying voice track) to subjects (usually college students), measuring their emotional responses (ascertained by physiological indicators as well as self-reports). Some candidates' facial images (for instance, Gary Hart in 1984) increased expressed regard for these individuals; the images of others (such as Fritz Hollings and Walter Mondale) yielded no such positive impact (Sullivan and Masters, 1988). Another variable that has been linked to political behavior is psychophysiological arousal, usually defined as the extent of physiological activation and energy mobilization typical of a person (Peterson, 1981; Schwartz and Zill, 1971). Research suggests that higher arousal goes with more political activity.

Some have reasoned that poor health leads to lower levels of political activity. This seems to be the case in studies conducted by Schwartz (1976; Schwartz et al., 1975). Two other studies, using samples of rural older Americans, suggest that poor health depresses levels of political activity (Peterson, 1987, 1989). Booth and Welch (1976), reviewing fairly complete and direct measures of health status from a sample of Toronto residents, concluded that health status bore little relationship to political activity level.

There has long been speculation about a linkage between nutrition and political behavior (see, for example, Davies, 1963). Bhaskaran (1982) reported that greater protein intake among citizens in a city in India covaried with greater political participation. Poor nutrition also seemed to be associated with modestly reduced levels of political behavior in a sample of rural elderly (Peterson, 1987). Body image is another factor that might predict political behavior given that more positive body images are associated with a greater sense of self-worth and self-confidence and, consequently, with higher levels of political participation. Schwartz et al. (1975) did indeed find such a correspondence.

\section{Elite political behavior}

Biopolitical researchers have also applied the concept of arousal to elite decision making behavior. G. Schubert (1985), observing Swiss judges in open court, discovered that higher levels of arousal (as measured by such indices as extent of judges' movements) correlate with social leadership on judicial panels, to conservative views, to lower status, and to low seniority. J. Schubert studied members of a small village council, employing voice pitch, pitch variation, voice intensity, and intensity variation to measure arousal. He concluded that conflict behavior is associated with higher levels of arousal and that "[a]rousal may play an important part in commanding attention from the group to the arguments presented and in promoting group confidence in them" (J. Schubert, 1986: 489).

Aging is another physiological variable that might influence elite behavior. Glendon Schubert (1983), analyzing Supreme Court decisions, stated that if justices change their voting behavior as they age, and change does not always occur, the shifts are in a conservative direction. This conclusion is consistent with his biologically-based hypothesis that aging tends to lead toward more conservative views (and see J. Schubert et al., 1986). James Schubert (1988b), relying on data from a sample of 24 local legislatures, concluded that older legislators were more passive as leaders.

Schwartz $(1976,1978)$ interviewed federal judges (see section on judicial behavior, below), members of Congress, and top-level administrators in Washington, DC. Less healthy decision-makers were more negative in their evaluation of the federal government. Administrators who were less healthy tended to interact less with other top government 
figures; in contrast, healthier members of Congress were more likely to engage in these interactions.

Gilbert (2003) called attention to the relationship between stress and elite behavior. Calvin Coolidge promised to be an active chief executive, but the stress resulting from his son's slow, lingering death led to a clinical depression that rendered him a "do nothing" president. Over time, Gilbert has explored the relationship between medical factors and presidential behavior for a number of presidents, including Dwight Eisenhower, Ronald Reagan, John F. Kennedy, and the like (for example, see Gilbert, 1998, 2000, 2003, 2008).

\section{Judicial Behavior and Public Law}

Three distinct research focuses can be identified here: (1) the biological factors related to judicial behavior; (2) biological explanations for the existence of laws; and (3) concern with the legal issues stemming from the life sciences (the latter is also a public policy issue, and we will treat this literature in that section below).

\section{Judicial behavior}

Schwartz (1978) gathered personal health information on 30 federal Courts of Appeals judges. His analysis indicated that: (1) less healthy judges are less active in interactions with other policy actors in Washington, DC; (2) less healthy judges have a lower overall evaluation of the federal government; and (3) healthier judges are more extroverted.

\section{Law as a biological phenomenon}

Kort contends that human neurophysiology predisposes people to accept lawlike prescriptions of behavior. Relying on Paul MacLean's concept of the limbic system (an older segment of the brain, often referred to as the seat of the emotions), Kort (1989: 9) argues that a portion of this brain structure provides "the foundation for a sense of responsibility to other members of the same species ... a responsibility that is the basis of all law, legal processes, and legal institutions." He also feels that law is an example of the genetic tendency to engage in "reciprocal altruism", that is, one helps others on the assumption that at some later point one will receive aid in return.

\section{Public Administration}

Biological factors may bear upon several dimensions of administrative behavior. These are briefly discussed in this section. Nancy Meyer-Emerick has provided us context when she observed that there has been "almost no discussion of biopolitical theory or method by that name in the public administration literature" in at least the last twenty-five years (2007: 690). A recent article in a flagship journal in public administration, Public Administration Review, acknowledges the potential value of evolutionary psychology, although the authors do not seem aware of pre-existing biopolitical literature on the subject (Tybur and Griskevicius, 2012).

Next, we consider some of the extant literature, to show that students of biology and politics have been considering the relevance of biological factors for public administration for quite some time. 


\section{Bureaucratic pathology}

Somit (1986) points out the probability of a genetic basis for certain bureaucratic pathologies, such as the tendency of bureaucrats and bureaucracies to advance their own agendas and/or personal interests at the expense of that elusive objective, the general good. In similar fashion, O'Hara (1982) has commented that bureaucratic infighting and turf conflict are akin to the hierarchical and territorial behavior characteristic of many other species.

\section{Origin and development of bureaucracy}

Adrian (1970: 7) suggests that an innate need for cooperation explains in part the origin of bureaucracy: "Participation in organizational activities and goals . . . can be viewed as innately satisfying to the individual as part of his preprogrammed commitment to group preservation." Gulick (1977) also believes that bureaucracy helps to fulfill a genetically based concern for one's fellow humans.

On the other hand, Caldwell argues that sociobiology confronts bureaucracy with a serious challenge, for it calls into question assumptions long accepted in public administration. "An apparent human tendency to develop large, impersonal, centralized bureaucracies to cope with social needs," he holds, "could be a monumental error compounded by man's misunderstanding of his innate needs and limitations" (Caldwell, 1980: 2). Since humans evolved in small, face-to-face groups, we may not be programmed to function well in impersonal bureaucratic structures. Large-scale bureaucratic society may therefore be doomed to fail. Flohr (1986) describes the frustrating experience that people often have in dealing with bureaucrats and discusses some biosocial consequences, including clients who suffer from stress as a result of their bureaucratic encounters.

\section{Political Philosophy}

Somit (1981) has described in some detail the manner in which different notions of the nature of human nature are connected with almost all of the major issues in political philosophy. Addressing another central question, the origin and nature of the state, Masters (1983) contends that the state emerged as a result of the interaction between in-group cooperation and competition among different groups.

Axelrod (1984) used game theory to indicate that a "tit for tat" strategy in cooperation would make sense in evolutionary terms, that is, if others cooperate with you, you cooperate with them; if they do not cooperate with you, you reciprocate and do not cooperate with them. This is deemed an "evolutionary stable strategy" (ESS). From such cooperation, political society and the state would presumably emerge. Others claim that the study of human biology may provide the basis for a re-analysis of natural law, with biology suggesting basic governing principles for human behavior (for example, Hartigan, 1988).

Roger Masters (1993; see also Masters, 1989) has attempted to derive a naturalistic ethics from evolutionary theory (and see Arnhart, 1998). According to Masters, neoDarwinism provides a means of resolving the "is-ought" issue that has so long been debated by political philosophers. It is as yet unclear what impact this line of argument has had on the discipline.

Finally, Somit and Peterson (1997) offered a neo-Darwinian explanation for the rarity of democratic polities both historically and even today, during the so-called "Age of 


\section{Handbook of biology and politics}

Democracy." The explanation is to be found in our species' evolutionary history. Over literally millions of years, natural selection has endowed Homo sapiens, as it did the other social primates, with an innate bias toward hierarchical social and political structures. This innate tendency is a major - but not the only - reason why the overwhelming majority of political societies have been and continue to be authoritarian in nature. Thus far, this Darwinian explanation for the pervasiveness of authoritarianism has failed to garner widespread notice and support. A case study applying this formula to Iraq and Afghanistan concludes that the odds are low that democracy will emerge in either venue in the not-too-distant future.

\section{International Relations}

The literature of international relations tends to fall into broad categories, two of which are: (1) decision-making in crisis situations; and (2) the problem of war.

\section{Decision making}

Wiegele (1976) holds that stress, fatigue, and possibly poor health, increase the probability of poor quality decisions.

\section{Warfare and conflict}

Strate (1985) used sociobiological theory to explain the origins of war, arguing that social groups emerged as a means of protecting individuals against attacks by other groups. This tendency to band together for defense against outside threats enhanced survival and, consequently, eventually became a part of our genetic make-up. Willhoite (1977), noting that many primate societies exhibit xenophobic behavior (that is, hostility toward outsiders), speculates that human suspicion of, and aggression toward, other groups and societies might have a similar genetic basis. Thayer (2009) has contended that humans fight wars along the lines predicted by evolutionary theory. His wide-ranging coverage of this issue is one of the more important contributions in this area.

\section{Comparative Politics}

Biopolitical work in comparative politics has largely dealt with political development, internal political conflict and change, and comparative biopolicy. Each topic is treated in turn.

\section{Political development}

According to Stauffer (1969), malnutrition, parasitic disease and the like undermine a country's ability to achieve the mobilization regarded as a precondition for national development. In a later work, Stauffer (1970) argues that colonial powers have sometimes encouraged or facilitated the use of drugs (such as alcohol) in order to make a population more quiescent and thus retard political development. Peterson has found that health and nutrition status, under certain circumstances, appear to be associated with greater democratization across different countries (Peterson with Franzese, 2015).

Corning (1983) formulated a general evolutionary model that he applies to political development. For Corning (1982: 1), political society is a cybernetic system: "Positive 
synergistic (combinatorial) effects of various kinds have been the underlying cause of 'progressive' sociocultural and political evolution." This synergistic feature of evolution, he says, has led to increasingly complex, hierarchically organized political systems.

\section{Internal conflict, violence, and revolution}

Welch and Booth (1974) identified a modest relationship between crowding within a country and the likelihood of internal violence. Their underlying supposition is that crowding, through intervening physiological mechanisms, increases the likelihood of aggressive behavior. Diminished levels of nutrition may, if not debilitating, yield frustration among a people, producing "local food riots, which may broaden and deepen into revolution" (Davies, 1963: 15). J. Schubert (1981) concludes that in moderately repressive societies, the greater the malnutrition, the greater the chance of political violence.

\section{Comparative policy choices}

Sven Steinmo (2010) has constructed a perspective that applies evolutionary theory to explaining policy choices across countries. This book compares Sweden, Japan, and the United States. He contends that social systems, like living organisms, change, adapt, and evolve. He looks at how the three countries have addressed policy domains involving the tax system, welfare policy, and political economies. As the three systems have evolved over time, the end result has been very different ways of addressing these issues.

\section{Public Policy}

The public policy issues related to recent advances in the life sciences are a boom area for biopolitics. Regrettably, we can only touch on a few of the major topics receiving attention. Carmen (1986) has dealt with constitutional issues related to DNA research. J. Schubert (1986) has looked at the impact of food aid programs on ameliorating food shortages. He has also addressed some of the policy questions posed by AIDS (J. Schubert, 1988a). Corning (2012) has used evolutionary theory to call for a more fair society. His argument notes that this can be done within an evolutionary framework.

Among other issues that have been considered are: allocation of scarce, and expensive, medical resources; euthanasia; the genetic and physiological bases of criminal behavior; biological roots of national security and foreign policy; life extending technologies; sex selection technologies; biological warfare; agricultural biopolicy; effects of neurotoxins on criminal behavior; conservation policy (addressing threats of extinction for many species); sex preselection; and population policy (for volumes addressing a number of these issues, see Somit and Peterson, 2003, 2011; Wiegele, 1985; Funke, 2013, 2014).

\section{THIS VOLUME}

The chapters in this volume break out as follows. Part I provides an overall introduction to the field of biology and politics. In the first chapter here, Steven Peterson and Albert Somit outline the biology and politics field plus a summary of the volume. Robert Sprinkle provides a history of biopolitics, placing it in a broader context, including an exploration of the organizational structure of this area. Allan Mazur provides a sense of 
the public's ambiguous views of evolutionary theory (itself the ultimate theoretical touchpoint for biopolitics). Finally, Vanessa Lemm and Miguel Vatter summarize an alternative perspective on biopolitics from the orientation of Michel Foucault. This perspective takes a different path from most of the chapters in this book (for example, see Liesen and Walsh, 2012). But it has become a widely known approach to the linkage of biology to politics and, as such, ought to be included in this volume.

Part II explores general biological approaches to politics. Evolutionary theory, of course, is the base of the biological orientation toward the study of politics. Peter Corning, with his usual command of the literature, speaks to the evolution of politics from a biological viewpoint. One promising area of research in biopolitics is the linkage between genes and politics. Aleksander Ksiazkiewicz and Amanda Friesen explore this approach. Robert Blank discusses the importance of the brain sciences for understanding politics. Finally, Michael Bang Petersen considers the value of evolutionary psychology for the study of political psychology.

In Part III the volume looks at the contributions of biology in the various fields of political science. Albert Somit conducts a broad gauge survey of political philosophy. John Friend and Brad Thayer inquire into the linkage between biology and international politics. Then, Werner Patzelt provides a survey of the value of biology in the study of comparative politics. Albert Somit and Steven Peterson investigate the relevance and value of biology for our understanding of research methods. Ken Blanchard follows with another philosophically oriented essay: the value of biology for our understanding of political ethics. Ron White considers the contributions of biology to our comprehension of leadership and followership. In a related inquiry, Gregg Murray explores the understanding of mass political behavior from a biological view. Joseph Losco's examination of the biology-public administration association follows. Erik Bucy applies biopolitics to the arena of political communication. Odelia Funke, a pioneer in biopolicy, lays out the linkage between biology and public policy. Finally, Bobbie Foster and Patrick Stewart discuss an important biologically oriented research perspective: observation. Famous ethologists broke new ground in focusing on actual observation of the behavior of a variety of animal species. This chapter applies that sensibility to human political behavior.

Part IV is oriented toward the interaction of biology and public policy. The array of subjects indicates the importance of taking biology seriously. Danielle Boisvert and Jamie Vaske explore the relevance of biology for criminal justice policy. Tony Wohlers speaks of the importance of biology for agricultural policy. Roger Masters has long studied the impact of neurotoxins on policy; he gives the readers a summary of his key work. Peter Corning contends that biology can teach us about the value of a social contract, in which we take into account the needs of those who are less fortunate. Kent Butts pursues the importance of climate change for national and homeland security. Laurette Liesen examines the relationship between biology and aspects of children's reproductive strategies, an example of research in the area of women and politics. Michael Latner examines the hot button issue of the relevance of biology for democracy. Amy Fletcher steps back to look at the future policy implications emanating from biology. Finally, Denis Couvet writes of the important biopolicy issue of biodiversity.

The final section, Part V, features two chapters reflecting upon the biopolitical enterprise. Steven Peterson and Albert Somit summarize a handful of controversies in biology and politics to remind us that we need to have a critical take on the subject, understanding 
that there are very different views on key issues. Finally, the same two authors concisely consider the future of the biopolitical perspective.

\section{REFERENCES}

Adrian, Charles (1970). Ethology and bureaucracy. Paper presented at the International Political Science Association meeting, Munich.

Alford, J.R., C. Funk and J.R. Hibbing (2005). Are political orientations genetically transmitted? American Political Science Review, 99, 153-67.

Amodio, David M., John T. Jost, Sarah L. Master and Cindy M. Yee (2007). Neurocognitive correlates of liberalism and conservatism. Nature Neuroscience, 10, 1246-7.

Arnhart, Larry (1998). Darwinian Natural Right. Albany, NY: SUNY Press.

Axelrod, Robert (1984). The Evolution of Cooperation. New York: Basic Books.

Barash, David P. (1982). Sociobiology and Behavior, 2nd edn. New York: Elsevier.

Bhaskaran, S. (1982). Linkage between malnutrition and political apathy. Paper presented at the International Political Science Association, Rio de Janeiro.

Bluntschli, J.K. (1895). The Theory of the State, English edn. Oxford: Clarendon Press.

Bodin, Jean (1962). The Six Books of a Commonweale, reprint of 1606 English translation. Cambridge, MA: Harvard University Press.

Booth, Alan and Susan Welch (1976). Stress, health, and political participation. Paper presented at the International Political Science Association, Edinburgh.

Boudreau, Cheryl, Seana Coulson and Mathew McCubbins (2008). The effects of institutions on behavior and brain activity. Paper presented at the Midwest Political Science Association, Chicago, IL.

Burgess, John W. (1890). Political Science and Comparative Constitutional Law. Boston, MA: Ginn.

Caldwell, Lynton K. (1964). Biopolitics: Science, ethics, and public policy. The Yale Review, 54, 1-16.

Caldwell, Lynton K. (1980). Biology and bureaucracy: The coming confrontation. Public Administration Review, 40, 1-12.

Carmen, Ira (1986). Cloning and the Constitution. Madison, WI: University of Wisconsin Press.

Charney, Evan (2011). Political science and behavior genetics. In Albert Somit and Steven A. Peterson (eds), Biology and Politics: The Cutting Edge. Bingley: Emerald Publishing.

Corning, Peter (1982). Political development versus political evolution. Paper presented at the Northeastern Political Science Association meeting, New Haven, CT.

Corning, Peter (1983). The Synergism Hypothesis. New York: McGraw-Hill.

Corning, Peter (2012). The Fair Society. Chicago, IL: University of Chicago Press.

Darwin, Charles (1859). On the Origin of Species. London: John Murray.

Davies, J.C. (1963). Human Nature in Politics. New York: John Wiley.

Dealey, James Quayle (1921). The State and Government. New York: D. Appleton and Company.

Flohr, Heiner (1986). Bureaucracy and its clients. In: Elliott White and Joseph Losco (eds), Biology and Bureaucracy. Lanham, MD: University Press of America.

Founder's Forum (2011). Founder's Forum. Politics and the Life Sciences, 30 (1), 50-106.

Fowler, J.H. and D. Schreiber (2008). Biology, politics, and the emerging science of human nature. Science, 322 , 912-14.

Funke, Odelia (2013). Biopolicy: Can it provide a new paradigm? In Albert Somit and Steven Peterson (eds), The World of Biology and Politics. Bingley: Emerald Publishing.

Funke, Odelia (2014). Biopolicy: Social issues. In Robert H. Blank et al. (eds), Politics and The Life Sciences: The State of the Discipline. Bingley: Emerald Publishing.

Galton, Sir Francis (1892). Hereditary Genius, 2nd edn. London: Macmillan.

Gettell, Raymond (1933). Political Science. Boston, MA: Ginn.

Gilbert, Robert (1998). The Mortal Presidency, 2nd edn. New York: Fordham University Press.

Gilbert, Robert (2000). Managing Crisis: Presidential Disability and the Twenty-Fifth Amendment. New York: Fordham University Press.

Gilbert, Robert (2003). The Tormented President: Calvin Coolidge, Death, and Clinical Depression. Westport, CT: Praeger Publications.

Gilbert, Robert (2008). Eisenhower's heart attack. Politics and the Life Sciences, 27, 2-21.

Goetze, D. (2013). Communicating biopolitical knowledge through the Association for Politics and the Life Sciences. In A. Somit and S. A. Peterson (eds), The World of Biology and Politics: Organization and Research Areas. Bingley: Emerald Group Publishing.

Goodin, R.E. (ed.) (2009a). The Oxford Handbook of Political Science. Oxford: Oxford University Press. 
Goodin, R.E. (2009b). The state of the discipline, the discipline of the state. In R.E. Goodin (ed.), The Oxford Handbook of Political Science. Oxford: Oxford University Press.

Goodin, R.E. and H-D. Klingemann (eds) (1996). The Oxford Handbook of Political Science. Oxford: Oxford University Press.

Grant, Madison (1923). The Passing of the Great Race. New York: Scribner's.

Gulick, Luther (1977). Democracy and administration face the future. Public Administration Review, 37, 706-11.

Hamilton, W.D. (1964). The genetical evolution of social behavior. Journal of Theoretical Biology, 7, 1-52.

Hartigan, Richard Shelley (1988). The Future Remembered: An Essay in Biopolitics. Notre Dame, IN: Notre Dame University Press.

Hines, S.M., Jr (1982). Biopolitics and the evolution of inquiry in political science, 1 (1), 5-16.

John of Salisbury (1990). Policraticus, first published in 1159. Cambridge: Cambridge University Press.

Johnson, G.R. (2011). Politics and the life sciences: An unfinished revolution. Politics and the Life Sciences, 30 (2), 43-64.

Kanai, Ryota, Tom Feilden, Colin Firth and Geraint Rees (2011). Political orientations are correlated with brain structure in young adults. Current Biology, 21, 677-80.

Klemmensen, Robert, Peter Hatemi, Sara Binzer Hobolt, Inge Petersen, Axel Skytthe and Asbjorn Norgaard (2012). The genetics of political participation, civic duty and political efficacy across cultures. Journal of Theoretical Politics, 24, 409-27.

Kort, Fred (1989). Implications of biopolitics for the study and practice of law. Paper presented at the American Political Science Association meeting, Atlanta, GA.

Lasswell, H.D. (1956). The political science of science. American Political Science Review, 50 (4), 961-79.

Lasswell, H.D. (1968). The future of the comparative method. Comparative Politics, 1 (1), 3-18.

Liesen, L.T. and M.B. Walsh (2012). The competing meanings of "biopolitics" in political science. Politics and the Life Sciences, 31 (1-2), 2-15.

Mackenzie, W.J.M. (1967). Politics and the Social Sciences. Baltimore, MD: Penguin.

Mackenzie, W.J.M. (1977). Biopolitics and the naturalistic fallacy. Paper presented at the International Political Science Association Conference on Biology and Politics, Bellagio.

Marsiglio of Padua (1956). The Defender of Peace, trans. Alan Gewirth. New York: Harper and Row.

Masters, Roger D. (1983). The biological nature of the state. World Politics, 35, 161-93.

Masters, Roger D. (1989). The Nature of Politics. New Haven, CT: Yale University Press.

Masters, Roger D. (1993). Beyond Relativism. Hanover, NH: University Press of New England.

Masters, Roger D., Denis G. Sullivan, John T. Lanzetta, G.J. McHugo and Basil G. Englis (1986). The facial displays of leaders. Journal of Social and Biological Structures, 9, 319-43.

Mayr, Ernst (1963). Animal Species and Evolution. Cambridge, MA: Harvard University Press.

Meyer-Emerick, Nancy (2007). Public administration and the life sciences. Administration \& Society, 38, 689-708.

O'Hara, Patrick (1982). Reflections and reflexion of the making of foreign policy. Paper presented at the Northeastern Political Science Association meeting, New Haven, CT.

Peterson, Steven A. (1976). Biopolitics: lessons from history. Journal of the History of the Behavioral Sciences, 12, 354-66.

Peterson, Steven A. (1981). Psychophysiological arousal as a predictor of student protest. Journal of Political Science, 8, 108-13.

Peterson, Steven A. (1987). Biosocial predictors of older Americans' political behavior. Politics and the Life Sciences, 5, 246-51.

Peterson, Steven A. (1988). The health of the polity. Paper presented at the International Political Science Association meeting, Washington, DC.

Peterson, Steven A. (1989). You are what you eat: Nutritional status and political behavior among the elderly. Journal of Nutrition for the Elderly, 9, 51-66.

Peterson, Steven A. with Evan Franzese (2015). Health status, nutrition, and democracy: A cross-national study. Paper presented at the Midwest Political Science Association, Chicago, IL.

Pranger, R. (1967). Ethology and politics. Paper presented at the Southern Political Science Association meeting, New Orleans.

Schubert, Glendon (1976). Politics as a life science. In Albert Somit (ed.), Biology and Politics. The Hague: Mouton.

Schubert, Glendon (1983). Aging, conservatism, and judicial behavior. Micropolitics, 3, 135-79.

Schubert, Glendon (1985). Political Culture and Judicial Behavior, Volume 2. Lanham, MD: University Press of America.

Schubert, James N. (1981). Malnutrition and political violence. Paper presented at the Western Political Science Association meeting, Denver.

Schubert, James N. (1986). Human vocalizations in agonistic political encounters. Social Science Information, 25, 475-92. 
Schubert, James N. (1988a). Age and active-passive leadership style. American Political Science Review, 82, 763-72.

Schubert, James N. (1988b). Political decision-making and AIDS policy. Paper presented at the International Political Science Association meeting, Washington, DC.

Schubert, James N., Thomas C. Wiegele and Samuel M. Hines (1986). Age, Age Structure, and Political Decision Making, final report to the National Institute on Aging. DeKalb, IL: Northern Illinois University.

Schwartz, David C. (1976). Somatic states and political behavior. In Albert Somit (ed.), Biology and Politics. Paris: Mouton.

Schwartz, David C. (1978). Health status, self-image and political behavior in an American political elite. Paper presented at the Western Political Science Association meeting, Los Angeles.

Schwartz, David C. and Nicholas Zill (1971). Psychophysiological arousal as a predictor of political participation. Paper presented at the American Political Science Association meeting, Chicago, IL.

Schwartz, David C., J. Garrison and J. Alouf (1975). Health, body images, and political socialization. In David C. Schwartz and Sandra Kenyon Schwartz (eds), New Directions in Political Socialization. New York: The Free Press.

Smith, Kevin B. and Peter Hatemi (2013). OLS is AOK for ACE. Political Behavior, 35, 383-408.

Somit, A. (1968). Toward a more biologically oriented political science. Midwest Political Science Review, 12, $550-67$.

Somit, Albert (1981). Human nature as the central issue in political philosophy. In Elliott White (ed.), Sociobiology and Politics. Lexington, MA: D.C. Heath.

Somit, Albert (1986). Bureaucratic pathology, public administration, and the life sciences. In Elliott White and Joseph Losco (eds), Biology and Bureaucracy. Lanham, MD: University Press of America.

Somit, Albert and Steven A. Peterson (1997). Darwinism, Dominance, and Democracy. Westport, CT: Praeger.

Somit, Albert and Steven A. Peterson (eds) (2003). Human Nature and Public Policy. New York: Palgrave Macmillan.

Somit, Albert and Steven A. Peterson (eds) (2011). Biopolicy: The Life Sciences and Public Policy. Bingley: Emerald Publishing.

Somit, Albert and Steven A. Peterson (2013). International Political Science Association's Research Committee \# 12. In A. Somit and S.A. Peterson (eds), The World of Biology and Politics: Organization and Research Areas. Bingley: Emerald Publishing.

Spencer, H. (1969). The social organism, reprint edn. In Donald McCrae (ed.), The Man versus the State. Baltimore, MD: Penguin.

Stauffer, Robert (1969). The biopolitics of underdevelopment. Comparative Political Studies, 2, 361-87.

Stauffer, Robert (1970). The role of drugs in political change. Paper presented at the International Political Science Association meeting, Munich.

Steinmo, Sven (2010). The Evolution of Modern States: Sweden, Japan, and the United States. New York: Cambridge University Press.

Strate, John (1985). The role of war in the evolution of political systems and the functional priority of defense. Humboldt Journal of Social Relations, 12, 87-114.

Sullivan, John T. and Roger D. Masters (1988). 'Happy warriors': Leaders' facial displays, viewers' emotions, and political support. American Journal of Political Science, 32, 345-68.

Thayer, Bradley (2009). Darwin and International Relations: On the Evolutionary Origins of War and Ethnic Conflict. Lexington, KY: University Press of Kentucky.

Tybur, Joshua and Vladas Griskevicius (2012). Evolutionary psychology: A fresh perspective for understanding and changing problematic behavior. Public Administration Review, 73, 12-22.

Wahlke, John C. (1976). Observations of biopolitical study. In Albert Somit (ed.), Biology and Politics. The Hague: Mouton.

Wahlke, John C. (1979). Pre-behavioralism in political science. American Political Science Review, 73, 9-32.

Wallas, Graham (1908). Human Nature in Politics. London: Constable.

Welch, Susan and Alan Booth (1974). Crowding as a factor in political aggression. Social Science Information, 13, 151-62.

Wiegele, Thomas C. (1976). Health and stress during international crisis. Journal of Political Science, 3, $139-44$.

Wiegele, Thomas C. (1985). The biotechnology of sex preselection. Policy Studies Review, 4, 445-60.

Willhoite, Fred C. (1977). Evolution and collective intolerance. Journal of Politics, 39, 667-84.

Wilson, Edward O. (1975). Sociobiology. Cambridge, MA: Harvard University Press.

Wilson, Woodrow (1908). Constitutional Government in the United States. New York: Columbia University Press. 